Canadian University Music Review

Revue de musique des universités canadiennes

\title{
Maria Calderisi. Music Publishing in the Canadas, 1800-1867. Ottawa: National Lilbrary of Canada, 1981, x, 128
}

\section{Clifford Ford}

Numéro 2, 1981

URI : https://id.erudit.org/iderudit/1013754ar

DOI : https://doi.org/10.7202/1013754ar

Aller au sommaire du numéro

Éditeur(s)

Canadian University Music Society / Société de musique des universités canadiennes

\section{ISSN}

0710-0353 (imprimé)

2291-2436 (numérique)

Découvrir la revue

Citer ce compte rendu

Ford, C. (1981). Compte rendu de [Maria Calderisi. Music Publishing in the Canadas, 1800-1867. Ottawa: National Library of Canada, 1981, x, 128].

Canadian University Music Review / Revue de musique des universités canadiennes, (2), 228-231. https://doi.org/10.7202/1013754ar

All Rights Reserved (C) Canadian University Music Society / Société de musique des universités canadiennes, 1981
Ce document est protégé par la loi sur le droit d'auteur. L’utilisation des services d'Érudit (y compris la reproduction) est assujettie à sa politique d'utilisation que vous pouvez consulter en ligne.

https://apropos.erudit.org/fr/usagers/politique-dutilisation/ 


\section{BOOK REVIEWS/COMPTES RENDU DES LIVRES}

MARIA CALDERISI. Music Publishing in the Canadas, 1800-1867. Ottawa: National Library of Canada, 1981, x, 128.

In studying the development of music of a country, especially a relatively new country such as Canada, one cannot disregard the ancillary subjects such as the music industry, music education, or music administration. Anyone familiar with Canadian music history will be only too aware that these elements play a considerable role in our understanding of Canada's musical growth. Essentially the study of Canadian music is a study of sociology. How does a musical community take root and flourish over a relatively short period of three hundred years? To answer this question one must call upon all the elements which make up the musical community, not only composition and performance.

It is to this end that Maria Calderisi's Music Publishing in the Canadas, 1800-1867, in both English and French (the French text on inverted pages), is a welcome study. Not a large book, the study is divided into seven chapters with six appendices, a bibliography, and an index. There are fifty-three pages of text and forty-two pages of illustrations. The appendices consist of an index to and chronological list of books known to contain musical notation, a chronological list of newspapers and periodicals known to contain printed music, a directory of Canadian sheet music publishers and printers, a synoptic chart of Canadian sheet music publishers, and a checklist of A. \& S. Nordheimer plate numbers. It is in the appendices where the true value of this study can be found and where researchers and students will be able to glean facts and figures on the publishing industry before Confederation. As such, Calderisi's study will become a valuable reference book. But it is to the text of the book to which we turn to flesh out those bare facts.

At the opening of her Preface, the author draws attention to the scarcity of sources concerning Canadian publishing history. It is a sad fact that most archivists and librarians have, in the past, tended to regard musical Canadiana of insufficient significance to have paid much attention to collecting it. However, the collecting of sheet music carried on by Helmut Kallmann, Chief of the Music Division of the National Library since 1970, has provided sufficient material for a study of this particular category and it is not surprising to find Calderisi devoting over half of her book to it. Her other categories are books, newspapers, and periodicals containing music.

The second point the author makes in the Preface is that she has not included material from the Maritime region, the only other region in British North America active in music publishing before Confedera- 
tion, the reason being that few publications are housed at the National Library. While I can accept, as the English title indicates, that this study is limited to the central provinces, I do find it sad that the significance of the contribution made by such publishers as E.G. Fuller or James Dawson of Nova Scotia or the appearance of Stephen Humbert's Union Harmony in New Brunswick in 1801 should have to wait in relative obscurity for a similar study to be done - a sequel perhaps?

One is tempted then to view this study as an elaborate summary, with extensive annotations, of the holdings of the National Library. This statement is further supported by the character of the text. Calderisi is content to report or describe rather than analyze her findings; although, admittedly, the material included in this study would hardly carry the weight of much analysis. The parameters of the study are simply not broad enough. We have already mentioned the geographical restriction, but the time restriction also prevents her from including the most prolific period in Canadian music publishing: from Confederation to World War I. It was during this period that sheet music publishing dramatically accelerated - although perhaps this mass-produced material is not as intrinsically interesting - and that the first complete musical scores of large works by Canadian composers made their appearance.

But let us not dwell any longer on what this study does not attempt to achieve and turn, instead, to its accomplishments. It is a study of the beginnings of music publishing in one region of British North America, namely, the Canadas. As the author points out, Canadians were rather late to move into this area of musical endeavor, having contented themselves with importing published music from Britain and, more particularly, from the United States where music publishing had become well established before the end of the eighteenth century. In the first chapter, Calderisi provides some historical background to her study, including population figures for the two Canadas and descriptions of the typical forms of music-making enjoyed by Canadians. Chapters 2 to 4 deal with the three categories of music publishing, that is, books with music, newspapers and periodicals with music, and sheet music publishing, respectively. The chapters are, moreover, in chronological order in that they correspond with the order of appearance of the three categories of publication.

It is not surprising that the first music to be published should be of a religious nature (Le Graduel romain, 1800) followed by books of a pedagogical nature (Elementary Treatise on Music . . .TTraité élémentaire de musique ... 1828). As time went on, interest moved toward the publication of entertainment music found in periodicals (from 1838) and sheet music (from 1840), reflecting the changing role of music in a society which, with the opportunity of greaier leisure, took up the study of music, particularly singing and piano playing. 
In general, the author provides historical information on the individuals or firms active in the three categories of music publishing followed by examples of each publisher's product. On this point, I found the fourth chapter the best organized. Here a detailed discussion of A. \& S. Nordheimer of Toronto, with abundant illustrations, is followed by information on publishers from Hamilton, Montreal, and Quebec.

An interesting discussion of the difficulties for the historian of dating a publication of sheet music is also found in this chapter (pp. 48-54). Those who enjoy taking the role of detective will appreciate the significance of this section. The author enumerates three means of dating a piece of sheet music: the imprint, the plate number, and the engraver's name. The problem arises with the name of John Ellis, an engraver for several of Nordheimer's sheet music publications. Unfortunately Calderisi's explanation is rather difficult to follow at this point, for she tends to draw on facts which she has not fully explained. She provides three examples of sheet music - all stamped with John Ellis's name as engraver, and only one of which is illustrated - to make her point. She goes on to say:

Close examination of the above three pieces reveals that the punch styles are slightly different in each. However, an even greater difference is evident in The Dublin Waltzes [a fourth example] by Labitsky .... The characters in no way resemble the others supposedly engraved by Ellis, yet, in themselves are so distinct that they are readily recognizable (p. 49).

Recognizable as what? As having been engraved by Ellis? Eventually, after much re-reading and reading on (through a few more examples) one comes to the author's conclusion that Ellis must have been merely the engraver of certain title pages.

Calderisi's tendency to draw on facts or information she has yet to clarify is the only serious flaw in the book. It is most evident in the ordering of the chapters. Those not versed in printing processes and its terminology will find these three chapters at times difficult to comprehend. Reading on, however, one will find, in Chapter 5, a discussion of the various printing processes used in Canada at this time. It would seem, therefore, more advantageous for the uninitiated (and I include myself here) to begin with Chapter 5 (and for that matter with Chapter 6 as well which deals with copyright) before attempting Chapters 2 to 4 .

Furthermore, it is not until the sixth chapter that the reader is given a detailed picture of the intimate relationship of publishing/ printing between Canada and the United States. In fact, it is here that we discover that "almost all of Nordheimer's publications were engraved and probably printed in New York" (p. 90). This is a rather significant point considering that Nordheimer was "the most active 
and prolific, producing more by far than the combined total of all other pre-Confederation sheet music publishers" (p. 93).

It would only be fair to say that Chapters 5 and 6 helped to satisfy my need, expressed at the beginning of this review, for analysis of the subject, and in Chapter 7 we are given some of the author's conclusions. It must also be said that the author has, under her own self-imposed parameters, dealt with the subject thoroughly and with care. She may be commended for having produced a reference book - the first such study of its kind-which can serve as a model for future investigations of the publishing industry in this country. In the author's own words:

It must be recognized that the collecting of early Canadian music has not been long under way. It is hoped that the present study will stimulate more interest in this field, long neglected by historians, collectors and librarians alike. It will be found most fascinating, an almost unexplored territory, which can provide an insight into so many aspects of Canadian life: social preoccupations, musical taste, legal rights, printing and publishing, marketing, patriotism and artistic expression. It is a multi-dimensional approach, both visual and aural, to a better understanding of Canada's past and, through it, a keener appreciation of its present (p. 93).

Clifford Ford

KATHLEEN M. TOOMEY and STEPHEN C. WILliS, eds. Musicians in Canada: A Bio-Bibliographical Finding List. Ottawa: Canadian Association of Music Libraries, 1981, xiv, 185 pp.

It is perhaps unfortunate for the editors that this reviewer received her copy of the Encyclopedia of Music in Canada (1981) a few days before writing this review, for one cannot help but feel that the latter will, to some extent, diminish the need for Musicians in Canada. Nonetheless, this computerized index contains references to many musicians who might not be deemed worthy of encyclopedic coverage, hence supplementing the Encyclopedia of Music in Canada. It is a marked expansion (by 1700 new entries) of the Bio-Bibliographical Finding List of Canadian Musicians (1961).

The book is in two parts: the largest section lists musicians' names alphabetically along with birth/death dates, place of birth, a keyed (two letters plus one number) summary of their musical contributions, and a key (one letter plus one number) to bibliographic sources; the second section groups names according to their musical contributions. Prefacing this body of material are an introduction, keys to musical 